\title{
Solvatomorphism: the inclusion of unexpected guests. An interesting case of study of different solvates in the tecton $\left[\mathrm{Pd}(1,10-p h e n)\left(2,3,5,6-\mathrm{S}-\mathrm{C}_{6} \mathrm{~F}_{4} \mathrm{H}\right)_{2}\right]$
}

\author{
Juan Manuel Germán-Acacio, ${ }^{a}$ Hugo Juárez Garrido, ${ }^{\mathrm{b}}$ Reyna Reyes, Martínez, ${ }^{\mathrm{b}}$ and David Morales-Morales ${ }^{b}$ \\ ${ }^{a}$ Red de Apoyo a la Investigación, Instituto Nacional de Ciencias Médicas y Nutrición SZ-Universidad \\ Nacional Autónoma de México (CIC-UNAM), CDMX C.P. 14000, México. \\ b Instituto de Química, Universidad Nacional Autónoma de México, Circuito Exterior, Ciudad Universitaria, \\ México, CDMX. 04510, México.
}

\section{Keywords: Fluorinated Thiolates, Palladium, Solvatomorphism, Phenanthroline.}

In this work is described the crystalline structures of a non-solvated tecton $[\operatorname{Pd}(1,10-$ phen $)($ 2,3,5,6-S- $\left.\left.\mathrm{C}_{6} \mathrm{~F}_{4} \mathrm{H}\right)_{2}\right]$ (1) (phen = 1,10-phenanthroline) and three different solvatomorphs $\left[\mathrm{Pd}(1,10\right.$-phen $\left.)\left(2,3,5,6-\mathrm{S}-\mathrm{C}_{6} \mathrm{~F}_{4} \mathrm{H}\right)_{2}\right] \cdot \mathrm{S}, \mathrm{S}=\mathrm{C}_{6} \mathrm{H}_{6}(\mathbf{2}), \mathrm{S}=\mathrm{C}_{6} \mathrm{H}_{6}-\mathrm{Cl}$ (3) and $\mathrm{S}=\mathrm{C}_{6} \mathrm{H}_{6}-\mathrm{Br}$ (4). In addition is described the formation of the crystalline solvate $[\mathrm{Pd}(1,10-\mathrm{phen})(2,3,4,5,6-\mathrm{S}$ $\left.\left.\mathrm{C}_{6} \mathrm{~F}_{5}\right)_{2}\right] \cdot \mathrm{C}_{6} \mathrm{H}_{6}-\mathrm{Br}(5)$ for comparison purposes with the former compounds. In this case we are interested in getting deeper in the knowledge of the fascinating phenomena of solvatomorphism. Thus, we performed computational studies in order to elucidate the energetics involved of the non-solvated tecton and their solvatomorphs in attempt to establish how these unexpected guests are encrusted within the unit cell.

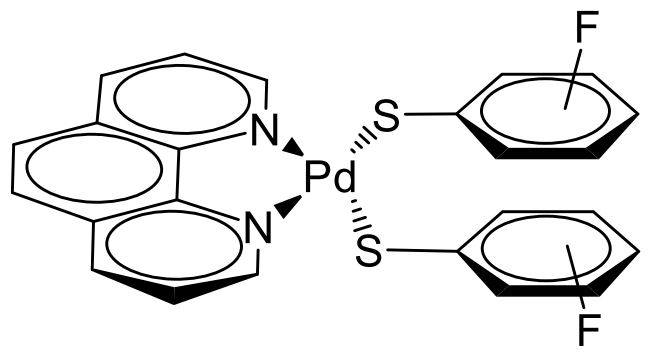

\section{Tectons}
(1) $\mathrm{SR}_{\mathrm{F}}=2,3,5,6-\left(\mathrm{C}_{6} \mathrm{~F}_{4} \mathrm{H}\right)$
(2) $\mathrm{SR}_{\mathrm{F}}=2,3,5,6-\left(\mathrm{C}_{6} \mathrm{~F}_{4} \mathrm{H}\right) \cdot \mathrm{C}_{6} \mathrm{H}_{6}$
(3) $\mathrm{SR}_{\mathrm{F}}=2,3,5,6-\left(\mathrm{C}_{6} \mathrm{~F}_{4} \mathrm{H}\right) \cdot \mathrm{C}_{6} \mathrm{H}_{6}-\mathrm{Cl}$
(4) $\mathrm{SR}_{\mathrm{F}}=2,3,5,6-\left(\mathrm{C}_{6} \mathrm{~F}_{4} \mathrm{H}\right) \cdot \mathrm{C}_{6} \mathrm{H}_{6}-\mathrm{Br}$
(5) $\mathrm{SR}_{\mathrm{F}}=2,3,4,5,6-\left(\mathrm{C}_{6} \mathrm{~F}_{5}\right) \cdot \mathrm{C}_{6} \mathrm{H}_{6}-\mathrm{Br}$ 